\title{
Laporan Kasus Berbasis Bukti Akurasi Modifikasi Skor Centor (McIsaac) dalam Mendeteksi Faringitis Grup A Streptokokus
}

Agustina Kadaristiana, Afiffa Mardhotillah, Nia Kurniati

Departemen Ilmu Kesehatan Anak Rumah Sakit Cipto Mangunkusumo, Jakarta

Latar belakang. Grup A streptokokus (GAS) merupakan penyebab utama faringitis bakterialis pada anak yang dapat menyebabkan komplikasi serius. Sayangnya, kultur swab tenggorok tidak selalu tersedia di fasilitas kesehatan yang terbatas.

Tujuan. Mengetahui akurasi modifikasi skor Centor (McIsaac) dibandigkan dengan kultur swab tenggorok dalam mendiagnosis faringitis GAS pada anak dengan nyeri tenggorok.

Metode. Penelusuran literatur dilakukan oleh dua orang melalui PubMed, Cochrane Library, dan DOAJ untuk mencari penelitian yang relevan. Kata teks dan $\mathrm{MeSH}$ digunakan dalam pencarian studi.

Hasil. Tiga studi memenuhi kriteria eligibilitas, tetapi hanya dua studi yang valid. Sensitivitas modifikasi skor Centor (McIsaac) $\geq 4$ berkisar antara 30,4\%-66,7\%. Sementara itu, spesifisitasnya memiliki rentang antara 69,6\%-87,6\%. Area under the curve (AUC) skor McIsaac adalah 78,1\%.

Kesimpulan. Modifikasi skor Centor (McIsaac) $\geq 4$ memiliki spesifisitas yang tinggi sehingga baik untuk mengidentifikasi faringitis GAS. Skor McIsaac bermanfaat sebagai tes triage yang menentukan perlu atau tidaknya kultur swab tenggorok. Sari Pediatri 2019;21(4):253-61

Kata kunci: McIsaac, modifikasi skor Centor, nyeri tenggorok, faringitis, grup A Streptokokus, Streptokokus pyogenes

\section{Evidence-Based Case Report The Accuracy of Modified Centor Score (McIsaac) in Detecting Group A Streptococcal Pharyngitis}

Agustina Kadaristiana, Afiffa Mardhotillah, Nia Kurniati

Background. Group A Streptococcus (GAS) is the most common cause of bacterial pharyngitis in children which may cause serious complications. Unfortunately, throat culture availability is somewhat limited.

Objective. To determine the accuracy of the modified Centor score (McIsaac) compared with a throat culture in diagnosing GAS pharyngitis in children with sore throat.

Method. We searched PubMed, Cochrane Library, and DOAJ to find relevant studies. Systematic reviews and cross-sectional studies that compared McIsaac score for GAS pharyngitis with a throat culture were included.

Results. Three studies were eligible for critical appraisal, but only two were valid. The sensitivity of McIsaac score $\geq 4$ is $30.4 \%$ to $66.7 \%$, and the specificity is $69.6 \%$ to $87.6 \%$. Area under the curve (AUC) McIsaac score is $78.1 \%$.

Conclusion. Modified Centor Score (McIsaac) $\geq 4$ has high specificity which is reliable in ruling-in GAS pharyngitis. The McIsaac score can be utilized as a triage test that determines the need for throat culture. Sari Pediatri 2019;21(4):253-61

Keywords: McIsaac, modified Centor score, sore throat, pharyngitis, group A Streptococcus, Streptococcus pyogenes

Alamat korespondensi: Agustina Kadaristiana. Departemen Ilmu Kesehatan Anak Fakultas Kedokteran Universitas Indonesia- RSCM, Jl. Pangeran Diponegoro no.71, Jakarta 10430. Email: kadaristiana@gmail.com 
Agustina Kadaristiana dkk: Akurasi modifikasi Skor Centor (McIsaac) dalam mendeteksi faringitis Grup A Streptokokus

$\mathrm{F}$ aringitis akut pada anak merupakan salah satu alasan utama pasien berkunjung ke klinik. ${ }^{1}$ Meskipun sebagian besar faringitis akut pada anak disebabkan karena virus, GAS merupakan penyebab utama faringitis bakterialis pada anak dan remaja dengan prevalensi mencapai $20 \% .^{2}$ Prevalensi ini jauh lebih tinggi daripada populasi dewasa, yaitu sekitar 5-10\%. ${ }^{3}$ Meskipun pada umumnya penyakit ini bersifat ringan, faringitis akut akibat grup A Streptokokus dapat menyebabkan komplikasi supuratif dan non-supuratif yang serius, ${ }^{4}$ seperti abses peritonsilar, penyakit jantung rematik dan glomerulonefritis pasca infeksi grup A Streptokokus. Oleh sebab itu, identifikasi infeksi grup A Streptokokus yang akurat diperlukan untuk tatalaksana dini sebagai pencegahan komplikasi. Keterlambatan dalam diagnosis dapat berkibat pada penggunaan terapi antibiotik yang tidak sesuai yang dapat menyumbang kejadian resistensi antibiotik..$^{5}$ Namun, penegakan faringitis GAS tidak mudah dilakukan, terutama di negara berkembang.

Hal ini disebabkan karena pada fasilitas yang terbatas, rapid test dan kultur swab tenggorok tidak selalu tersedia. Kriteria Centor telah lama digunakan pada populasi dewasa untuk memprediksi GAS dari hasil kultur berdasarkan empat kriteria klinis, yaitu demam $>38.5^{\circ} \mathrm{C}$, nyeri dan bengkak pada kelenjar getah bening servikal anterior, eksudat tonsil, tanpa disertai batuk. Apabila keempat kriteria ini positif, maka probabilitas GAS mencapai lebih dari 50\%. ${ }^{6}$ Skor Centor telah terbukti dapat menurunkan penggunaan antibiotik yang tidak diperlukan pada anak dengan faringits akut. Oleh sebab itu, skor modifikasi Centor (McIsaac) dikembangkan agar dapat memprediksi GAS pada populasi anak dengan menambahkan variabel kelompok usia (Tabel 1). ${ }^{7}$ Pada laporan kasus berbasis bukti ini, penulis bertujuan untuk menelaah literatur mengenai akurasi modifikasi skor Centor (McIsaac)

Tabel 1. Modifkasi skor Centor $\left(\right.$ McIsaac) ${ }^{7}$

\begin{tabular}{lc}
\hline Kriteria & Nilai \\
\hline Temperatur $>38^{\circ} \mathrm{C}$ & 1 \\
Tidak ada batuk & 1 \\
Pembersaran kelenjar getah bening & 1 \\
servikal anterior & \\
Pembesaran tonsil atau eksudat & 1 \\
Usia 3-14 tahun & 1 \\
Usia 15-44 tahun & 0 \\
Usia $\geq 45$ tahun & -1 \\
\hline
\end{tabular}

dibandingkan dengan kultur swab tenggorok dalam mendiagnosis faringitis GAS.

\section{Kasus}

Seorang anak perempuan berusia 12 tahun datang dengan keluhan nyeri tenggorokan. Keluhan disertai dengan suara yang serak dan nyeri kepala. Keluhan tidak disertai dengan batuk, pilek, dan demam. Ibu pasien mengukur suhu tubuh pasien secara berkala dengan hasil $36,7-37,2^{\circ} \mathrm{C}$. Pemeriksaan fisik didapatkan tanda-tanda vital dalam batas normal, faring hiperemis, dan pembesaran tonsil T1-T1 tanpa eksudat. Untuk memastikan apakah pasien mengalami faringitis akibat Grup A Streptokokus (GAS) yang memerlukan terapi antibiotik, dokter mempertimbangkan kultur swab tenggorok. Sayangnya, biaya kultur cukup mahal dan tidak selalu tersedia di tempat praktik. Dokter pernah mendengar mengenai modifikasi skor Centor/ McIsaac untuk mendeteksi faringitis GAS. Namun, dokter belum yakin bagaimana akurasi skor ini dalam mendiagnosis faringitis GAS dan apakah skor ini dapat digunakan di praktik sehari-hari.

\section{Masalah Klinis}

Berdasarkan skenario klinis dan pendahuluan di atas, pertanyaan klinis yang muncul adalah pada pasien anak dengan nyeri tenggorokan, bagaimana akurasi penggunaan modifikasi skor Centor (McIsaac) dibandingkan dengan kultur swab tenggorok dalam mengidentifikasi faringitis GAS?

\section{Metode}

Pertanyaan klinis (PICO) pada masalah ini adalah Patient (P): Anak dengan nyeri tenggorokan; Index test (I): modifikasi skor Centor (McIsaac); comparison (C): Kultur swab tenggorok; Outcome $(\mathrm{O})$ : Diagnosis faringitis Group A Streptococcus.

\section{Strategi pencarian}

Pencarian artikel dilakukan melalui database PubMed, Cochrane Library dan Direct Open Access Journal 
(DOAJ) untuk mengidentifikasi penelitian yang terpublikasi sampai Agustus 2019. Dalam pencarian literatur, Medical subject headings (MesH terms) dan text words digunakan dan dikombinasikan menggunakan operator Boolean, seperti AND dan OR. Limitasi pencarian tidak dilakukan pada jenis artikel dan bahasa.

\section{Kriteria seleksi}

Kriteria inklusi dari penelaahan literatur ini adalah original articles dengan desain penelitian systematic review dan studi potong lintang, studi dilakukan pada anak $\leq 18$ tahun, artikel dipublikasi dalam 25 tahun terakhir, tersedia data penelitian yang memungkinkan penghitungan akurasi tes, dan artikel berbahasa Inggris atau Indonesia. Adapun kriteria eksklusi yang digunakan adalah bayi $\leq 1$ tahun, reference standard yang digunakan bukan hanya kultur swab tenggorok, melainkan bercampur dengan pemeriksaan lain seperti rapid antigen detection test (RADT) dan molecular assays serta tidak tersedia full-text. Dua penulis melakukan penapisan judul dan abstrak secara independen berdasarkan kriteria inklusi dan eksklusi. Hasil telaah yang berkonflik akan diselesaikan melalui diskusi secara konsensus. Abstrak yang terseleksi kemudian dilakukan penapisan artikel full-text. Pada penapisan terakhir, artikel dieksklusi apabila tidak tersedia artikel full-text.

\section{Telaah kritis}

Seluruh artikel yang terpilih akan ditelaah secara kritis oleh kedua penulis menggunakan critical appraisal tool untuk studi diagnosis dari The Centre for Evidence-Based Medicine (CEBM), University of Oxford.

\section{Hasil}

Setelah dilakukan pencarian artikel pada PubMed, Cochrane, dan Direct Open Access Journal (DOAJ), didapatkan hasil pencarian database yang tertera ada Tabel berikut.

\section{Karakteristik studi}

Dari ketiga artikel yang memenuhi kriteria eligibilitas, dilakukan telaah kritis dengan menggunakan critical appraisal tool untuk studi diagnosis dari The Centre for Evidence-Based Medicine (CEBM). Ketiga studi tersebut menggunakan desain studi potong lintang serta berasal

Tabel 2. Strategi penelusuran literatur (dilakukan tanggal 27 Agustus 2019)

\begin{tabular}{|c|c|c|c|}
\hline Database & Terminologi pencarian & Rentang waktu & Artikel ditemukan \\
\hline $\begin{array}{l}\text { MesH Terms } \\
\text { dan text words - } \\
\text { PubMed }\end{array}$ & $\begin{array}{l}\text { (child[MeSH Terms]) OR children[Title/Abstract]) OR } \\
\text { pediatric[TitlelAbstract]) OR adolescent[MeSH Terms])) AND } \\
((\text { mcisaac) OR centor })) \text { AND }((((\text { streptococcus infections }[\mathrm{MeSH} \\
\text { Terms]) OR group A streptococcus[Title/Abstract]) OR streptococcal } \\
\text { infection[Title/Abstract]]) OR ((pharyngitis[Title/Abstract]]) OR } \\
\text { sore throat[Title/Abstract]])) }\end{array}$ & 25 tahun & 89 \\
\hline $\begin{array}{l}\text { MesH Terms } \\
\text { dan text words - } \\
\text { Cochrane }\end{array}$ & $\begin{array}{l}\text { \#1(Pediatric):ti, ab, kw OR (children):ti, ab, kw } \\
\text { OR (“Child"):ti,ab, } k w \text { OR (adolescent):ti,ab, kw (Word variations } \\
\text { have been searched) } 225167 \\
\text { \#2(centor):ti,ab, } k w \text { OR (McIsaac):ti, ab, kw (Word variations have } \\
\text { been searched) 9 } \\
\text { \#3(streptococcus infection):ti,ab, kw OR } \\
\text { (streptococcal infection):ti,ab, kw OR ("group A } \\
\text { Streptococcus"):ti,ab, kw (Word variations have been searched) } \\
2937 \\
\text { \#4 \#1 AND \#2 AND \#3 }\end{array}$ & 25 tahun & 7 \\
\hline $\begin{array}{l}\text { Text words - } \\
\text { DOAJ }\end{array}$ & Children, McIsaac, Centor, Pharyngitis, Group A Streptococcus & 25 tahun & 3 \\
\hline
\end{tabular}


PUBMED ( $\mathrm{n}=89$ ); Cochrane

Library $(n=7)$; DOAJ $(n=3)$

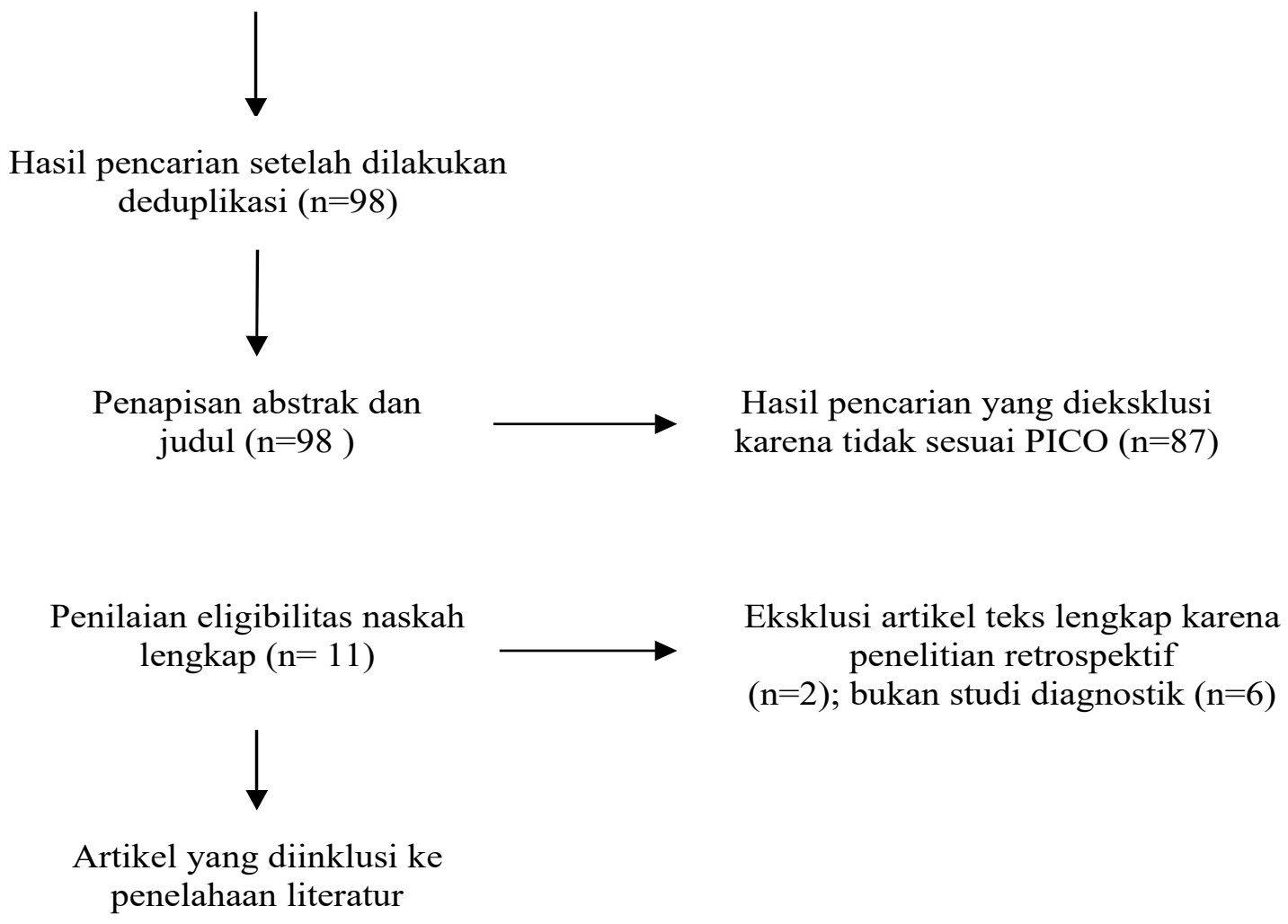

Gambar 1. Alur pemilihan literatur

dari berbagai negara, yaitu India, Amerika Serikat dan Indonesia. Dari segi pemeriksaan, seluruh artikel di atas merupakan penelitian yang menggunakan modified Centor Score (McIsaac Score) sebagai index test dan kultur swab tenggorok sebagai reference test.

Setelah dilakukan telaah kritis dari tiga studi, peneliti memutuskan bahwa hanya dua penelitian yang valid, yaitu Felsenstein dkk, ${ }^{9} 2014$ dan Malino dkk, ${ }^{10}$ (Tabel 5). Penelitian dari Vasudevan dkk, ${ }^{8} 2019$ dianggap tidak valid karena tidak menginklusi semua spektrum klinis faringitis. Selain itu, blinding tidak dilakukan pada subyeknya.

\section{Pembahasan}

Penelahaan tiga studi telah dilakukan oleh dua orang reviewer dan disimpulkan bahwa hanya dua artikel yang memenuhi aspek validitas. Penulis memutuskan untuk tidak menelaah aspek importance dan applicability penelitian Vasudevan $\mathrm{dkk}^{8}$ karena spektrum klinis yang berbeda dan tingginya risiko bias. Meskipun usia subyek penelitian Vasudevan $\mathrm{dkk}^{8}$ serupa dengan pasien dalam ilustrasi ini, tidak semua spektrum gejala dari faringitis dilibatkan. Selain itu, Vasudevan $\mathrm{dkk}^{8}$ tidak melakukan blinding dalam pengukuran. Dengan demikian, studi Vasudevan $\mathrm{dkk}^{8}$ berisiko untuk mengalami spektrum bias dan bias pengukuran. Mengenai dua studi yang valid, penulis menilai bahwa kualitas studi yang paling baik adalah Malino dkk. ${ }^{10}$ Subyek penelitian ini cukup representatif karena mencakup rentang usia dan spektrum klinis yang luas. Pasien yang menggunakan antibiotik juga dieksklusi. Selain itu, cara pengambilan sampel Malino $\mathrm{dkk}^{10}$ dengan consecutive sampling dinilai sudah tepat. Malino $\mathrm{dkk}^{10}$ juga melakukan blinding dalam pengukuran. Namun, Malino dkk ${ }^{10}$ tidak melibatkan anak berusia 14-18 tahun. Adapun kelemahan studi Felsenstein $\mathrm{dkk}^{9}$ 
Agustina Kadaristiana dkk: Akurasi modifikasi skor centor (McIsaac) dalam mendeteksi faringitis Grup A Streptokokus

Tabel 3. Karakteristik studi

\begin{tabular}{|c|c|c|c|c|}
\hline Artikel & $\begin{array}{l}\text { Desain studi/ } \\
\text { Level of } \\
\text { evidence }\end{array}$ & $\begin{array}{l}\text { Populasi (jumlah sampel, } \\
\text { metode sampling, dan } \\
\text { karakteristik) }\end{array}$ & $\begin{array}{l}\text { Index test dan } \\
\text { reference test }\end{array}$ & Luaran \\
\hline Vasudevan dkk, ${ }^{8}$ 2019/ India & $\begin{array}{c}\text { Potong } \\
\text { lintang/ level } 2\end{array}$ & $\begin{array}{c}\text { Usia } 1-18 \text { tahun } \\
\text { dengan gejala faringitis } \\
\text { dan dicurigai menderita } \\
\text { faringitis streptokokus } \\
\text { grup A, jumlah sampel } 120 \\
\text { orang. }\end{array}$ & $\begin{array}{c}\text { Index test: } \\
\text { Modified Centor } \\
\text { Score } \\
\\
\text { Reference test: kultur } \\
\text { swab tenggorok. }\end{array}$ & $\begin{array}{c}\text { Sensitivitas, } \\
\text { spesifisitas, PPV, } \\
\text { NPV, LR+, LR-, } \\
\text { AUC }\end{array}$ \\
\hline $\begin{array}{l}\text { Felsenstein dkk, }{ }^{9} \text { 2014/ } \\
\text { Amerika Serikat }\end{array}$ & $\begin{array}{c}\text { Potong } \\
\text { lintang/ level } 2\end{array}$ & $\begin{array}{l}\text { Sampel berjumlah } 69 \\
\text { pasien dengan rentang usia } \\
2 \text { bulan - } 18 \text { tahun. }\end{array}$ & $\begin{array}{l}\text { Index test: McIsaac } \\
\text { Scoring } \\
\text { Reference test: kultur } \\
\text { swab tenggorok }\end{array}$ & $\begin{array}{c}\text { Sensitivitas, } \\
\text { spesifisitas, PPV, } \\
\text { NPV, LR+,LR- }\end{array}$ \\
\hline Malino dkk, ${ }^{10} 2013 /$ Indonesia & $\begin{array}{c}\text { Potong } \\
\text { lintang/ level } 2\end{array}$ & $\begin{array}{c}\text { Sampel berjumlah } 114 \\
\text { pasien berusia 3-14 tahun. }\end{array}$ & $\begin{array}{c}\text { Index test: } \\
\text { Mc Isaac Scoring } \\
\\
\text { Reference test: } \\
\text { Kultur Swab } \\
\text { Tenggorok }\end{array}$ & $\begin{array}{c}\text { Sensitivitas, } \\
\text { spesifisitas, PPV, } \\
\text { NPV, LR+,LR-, } \\
\text { AUC }\end{array}$ \\
\hline
\end{tabular}

PPV=positive predictive value; NPV=negative predictive value; $\mathrm{LR}+=$ positive likelihood ratio; $\mathrm{LR}-=$ negative likelihood ratio

adalah tidak mengeksklusi pasien yang menggunakan antibiotik dan tidak menjelaskan cara pemilihan sampel.

Berdasarkan hasil yang didapatkan oleh kedua penelitian tersebut, secara umum, skor McIsaac memiliki angka spesifisitas yang lebih tinggi dibandingkan sensitivitasnya. Sensitivitas skor McIsaac $\geq 4$ berkisar antara 30,4\%-66,7\%. Sementara itu, spesifisitasnya memiliki rentang antara 69,6\%-87,6\%. Selain itu, modifikasi skor Centor (McIsaac) memiliki AUC yang cukup baik yaitu $78,1 \%$. Oleh karena itu, penulis berpendapat bahwa penggunaan modifikasi skor Centor sebagai alat uji diagnostik dapat bermanfaat untuk mengidentifikasi bahwa pasien dengan skor yang tinggi benar-benar menderita faringitis streptokokus grup A (me-rule in pasien yang benar-benar sakit). Adapun positive predictive value (PPV) bervariasi antara $31,6 \%-66,7 \%$ dan NPV yang memiliki rentang antara $33,3 \%-96,8 \%$. Namun, perlu dipertimbangkan bahwa variasi antara PPV dan NPV dapat disebabkan oleh perbedaan prevalensi penyakit pada kedua studi. Skor McIsaac sangat mungkin diaplikasikan pada pasien ini juga pada pasien di negara berkembang karena mudah digunakan.
Penulis menilai bahwa kedua studi dapat direplikasi dan diaplikasikan pada pasien. Namun, pada pasien kasus yang diilustrasikan ini, penulis lebih yakin menggunakan penelitian dari Malino dkk. ${ }^{10} \mathrm{Hal}$ ini disebabkan karena risiko bias pada studi Malino $\mathrm{dkk}^{10}$ lebih minimal dibandingkan dengan studi Felsenstein dkk. ${ }^{9}$ Studi Malino dkk ${ }^{10}$ mengekslusi pasien yang menggunakan antibiotik. Dari studi tersebut didapatkan hasil akurasi untuk skor modifikasi Centor $\geq 4$ yaitu sensitivitas $66,7 \%$, spesifisitas $87,6 \%$, PPV 31,6\%, NPV 96,8\%, LR+5,4, dan LR-0,4. Pada ilustrasi kasus, pasien berusia 12 tahun diketahui mengeluh nyeri tenggorokan tanpa disertai gejala lain, dengan kata lain pasien memiliki skor modifikasi Centor 1. Apabila prevalensi (pre-test probability) faringitis GAS dianggap sama dengan Malino dkk, ${ }^{10}$ yaitu $8 \%$, maka dengan hasil yang negatif (bukan $\geq 4$ ) didapatkan post-test probability 0,04 (Gambar 2). Hal ini menunjukkan bahwa kemungkinan pasien untuk mengalami faringitis GAS sangat kecil. Oleh sebab itu, pemeriksaan kultur dan pemberian antibiotik tidak perlu dilakukan. Skor modifikasi Centor (McIsaac) dapat digunakan sebagai pemeriksaan triage untuk membantu dokter menentukan keputusan untuk 
Agustina Kadaristiana dkk: Akurasi modifikasi Skor Centor (McIsaac) dalam mendeteksi faringitis Grup A Streptokokus

Tabel 4. Telaah kritis dari penelitian yang memenuhi kriteria inklusi

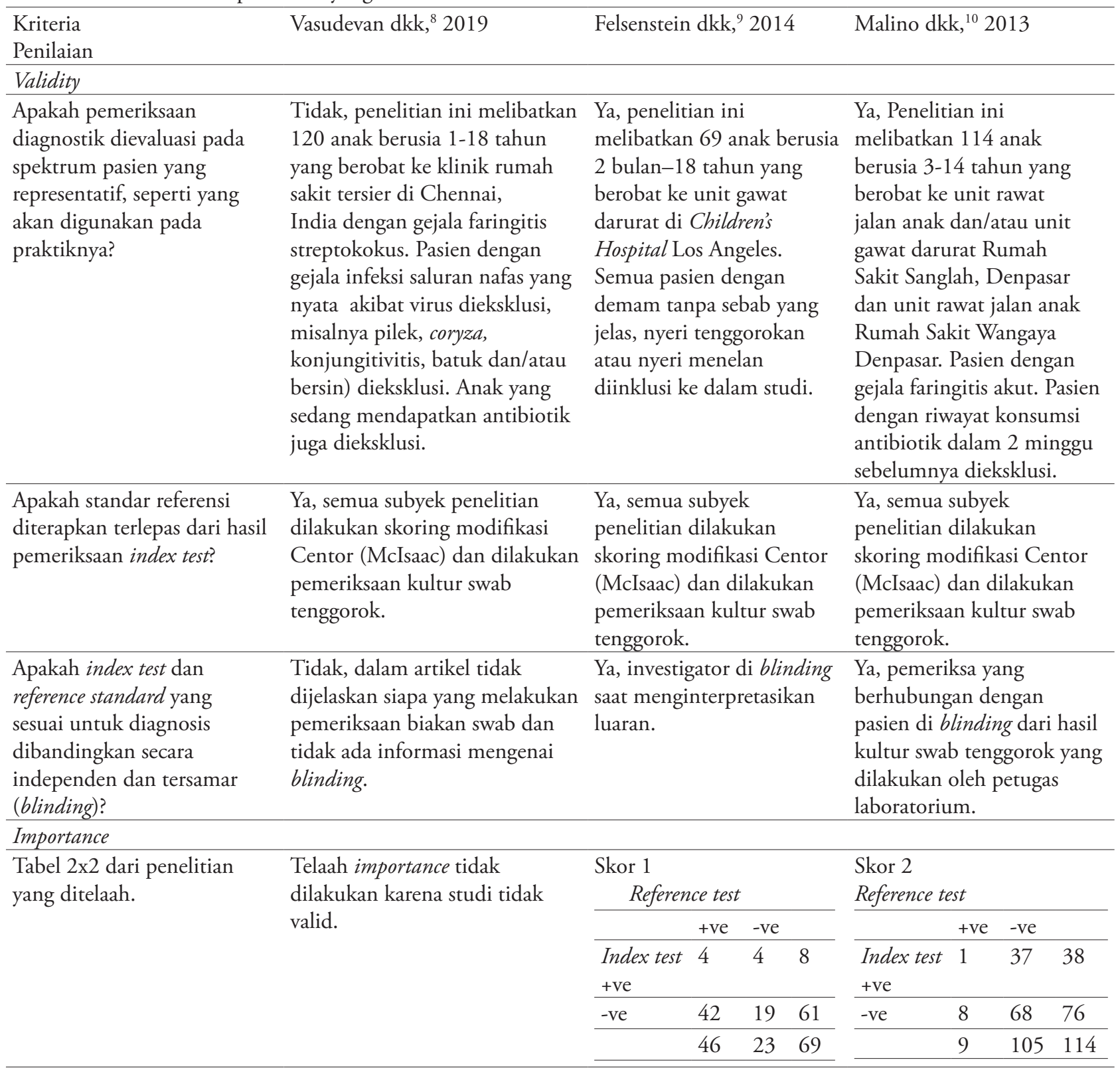


Agustina Kadaristiana dkk: Akurasi modifikasi skor centor (McIsaac) dalam mendeteksi faringitis Grup A Streptokokus

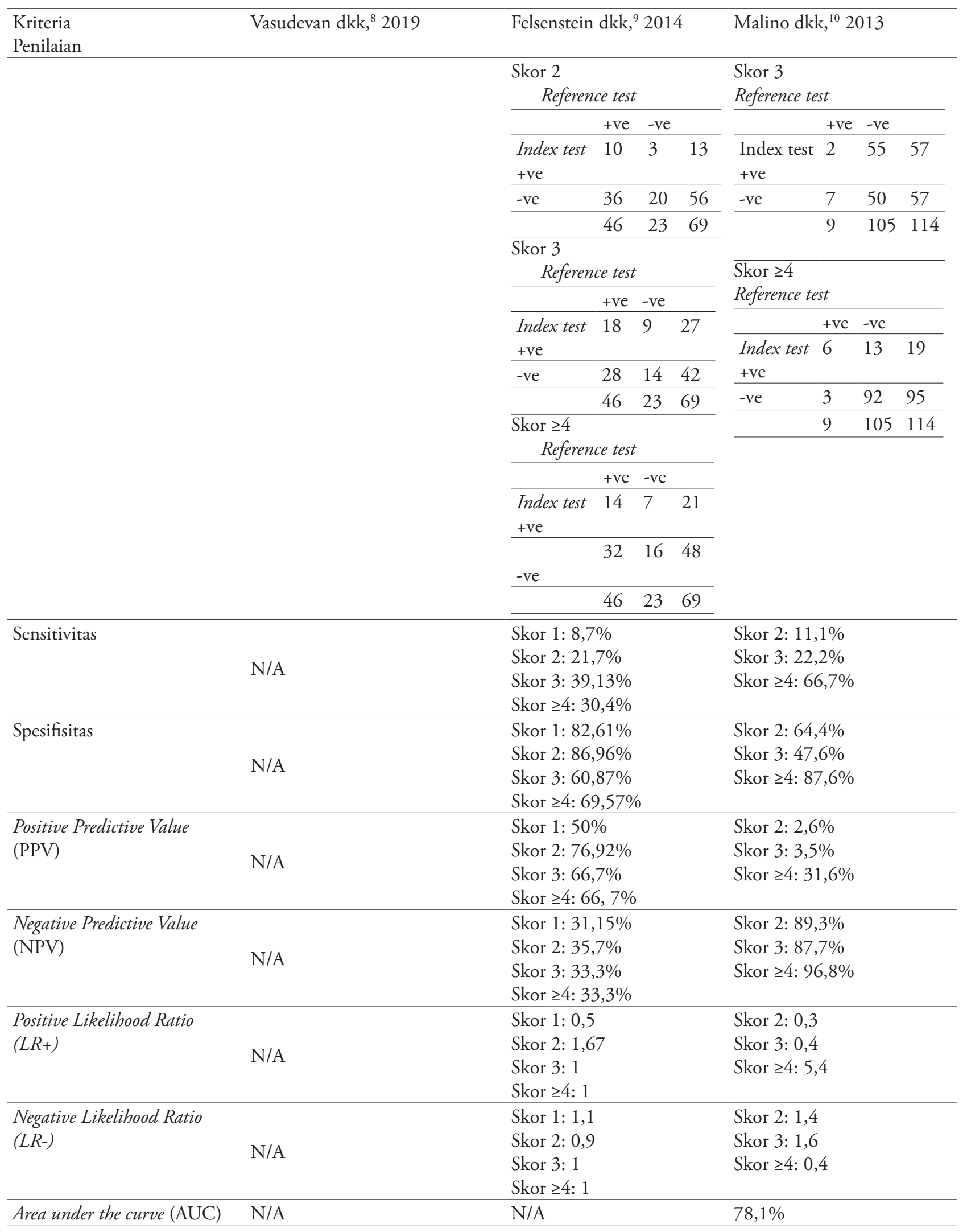


Agustina Kadaristiana dkk: Akurasi modifikasi Skor Centor (McIsaac) dalam mendeteksi faringitis Grup A Streptokokus

\begin{tabular}{|c|c|c|c|}
\hline $\begin{array}{l}\text { Kriteria } \\
\text { Penilaian }\end{array}$ & Vasudevan dkk, ${ }^{8} 2019$ & Felsenstein dkk, ${ }^{9} 2014$ & Malino dkk, ${ }^{10} 2013$ \\
\hline \multicolumn{4}{|l|}{ Applicability } \\
\hline $\begin{array}{l}\text { Apakah metode untuk } \\
\text { melakukan pemeriksaan } \\
\text { tersebut dijelaskan secara } \\
\text { rinci dan dapat direplikasi? }\end{array}$ & $\begin{array}{l}\text { Tidak, penelitian tidak bisa di } \\
\text { aplikasikan karena tidak valid. }\end{array}$ & $\begin{array}{l}\text { Ya, metode pemeriksaan } \\
\text { dijelaskan secara rinci dan } \\
\text { bisa direplikasi. Penelitian } \\
\text { ini menunjukkan bahwa } \\
\text { skor modifikasi Centor } \\
\text { (McIsaac) } \leq 2 \text { memiliki } \\
\text { spesifisitas yang tinggi. } \\
\text { Namun, sensitivitas skor } \\
\text { ini buruk berapapun } \\
\text { hasilnya. }\end{array}$ & $\begin{array}{l}\text { Ya, metode pemeriksaan } \\
\text { dijelaskan secara rinci dan } \\
\text { dapat di replikasi. Penelitian } \\
\text { ini menunjukkan skor } \\
\text { McIsaac memiliki nilai } \\
\text { AUC } 78,1 \% \text { yang berarti } \\
\text { memiliki nilai diagnostik } \\
\text { yang baik. }\end{array}$ \\
\hline
\end{tabular}

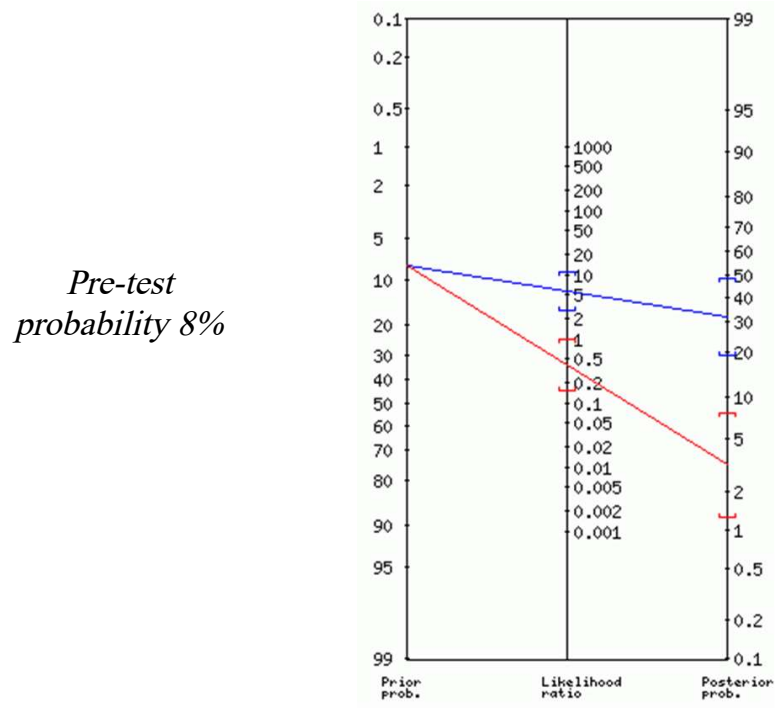
Post-test probability
(test positif) $32 \%$
Negative post-test
probability (tes
negatif) $4 \%$

Gambar 2. Fenton nomogram skor modifikasi Centor (McIsaac) $\geq 4$. Pre-test probability berdasarkan prevalensi adalah 8\%. Post-test probability dari hasil positif (garis biru) 32\%, sedangkan dari hasil negatif (garis merah) 4\%. Nomogram dihasilkan dari Diagnostic test calculator software. ${ }^{11}$

melakukan kultur atau tidak. Penggunaan modifikasi skor Centor (McIsaac) juga dapat mengurangi penggunaan antibiotik yang tidak sesuai.

\section{Kesimpulan}

Modifikasi skor Centor (McIsaac) bermanfaat untuk membantu mendiagnosis faringitis GAS. Skor ini memiliki spesifisitas yang cukup tinggi, namun sensitivitas yang rendah. Spesifisitas yang tinggi dapat meminimalisir jumlah positif palsu. Artinya, skor ini baik untuk me-rule in faringitis GAS. Namun, alat ini tidak bisa digunakan untuk skrining karena sensitifitas yang rendah. Dalam praktik klinis seharihari, modifikasi skor Centor (McIsaac) dapat berfungsi sebagai pemeriksaan triage untuk menentukan perlu atau tidaknya dilakukan kultur.

\section{Daftar pustaka}

1. Gereige R, Cunill-De Sautu B. Throat infections. Pediatr Rev 2011;32:459-69.

2. Kronman MP, Zhou C, Mangione-Smith R. Bacterial prevalence and antimicrobial prescribing trends for acute respiratory tract infections. Pediatrics 2014;134:e956-65. 
3. Ebell MH, Smith MA, Barry HC, Ives K, Carey M. Does this patient have Strep throat? JAMA 2000;284:2912.

4. Centers for Disease Control and Prevention (CDC). Group A Streptococcal (GAS) disease [Internet]. Diunduh pada 28 Agustus 2019 . Didapat dari: https://www.cdc.gov/groupastrep/ diseases-hcp/strep-throat.html.

5. Van Brusselen D, Vlieghe E, Schelstraete P, De Meulder F, Vandeputte C, Garmyn K, dkk. Streptococcal pharyngitis in children: to treat or not to treat? Eur J Pediatr 2014;173:1275-83.

6. Centor RM, Witherspoon JM, Dalton HP, Brody CE, Link $\mathrm{K}$. The diagnosis of strep throat in adults in the emergency room. Med Decis Mak 1981;1:239-46.

7. Mclsaac WJ, White D, Tannenbaum D, Low DE. A clinical score to reduce unnecessary antibiotic use in patients with sore throat. Can Med Assoc J 1998;158:75-83.

8. Vasudevan J, Mannu A, Ganavi G. McIsaac modification of Centor score in diagnosis of Streptococcal pharyngitis and antibiotic sensitivity pattern of Beta-hemolytic Streptococci in Chennai, India. Indian Pediatr 2019;56:49-52.

9. Felsenstein S, Faddoul D, Sposto R, Batoon K, Polanco CM, Bard JD. Molecular and clinical diagnosis of group A streptococcal pharyngitis in children. J Clin Microbiol 2014;52:3884-9.

10. Malino IY, Utama DL, Soenarto Y. McIsaac criteria for diagnosis of acute group-A $\beta$-hemolytic streptococcal pharyngitis. Paediatr Indones 2016;53:258.

11. Schwartz A. Diagnostic test calculator. 20100421012006. Diakses 20 Desember 2019. Didapat dari: http://araw.mede. uic.edu/cgi-bin/testcalc.pl. 